\title{
KONSUMSI PANGAN, PENYAKIT INFEKSI, SOSIAL EKONOMI BERHUBUNGAN DENGAN STATUS GIZI BALITA DI PERMUKIMAN KUMUH PADA MASA COVID-19
}

\author{
Stefany Lubis ${ }^{1}$, Mertien Sa'pang ${ }^{2}$, Laras Sitoayu ${ }^{3}$, Putri Ronitawati ${ }^{4}$, Anugrah Novianti ${ }^{5}$ \\ ${ }^{1,5}$ Program Studi Gizi, Fakultas Ilmu-Ilmu Kesehatan Universitas Esa Unggul \\ ${ }^{2,3,4}$ Program Studi Pendidikan Profesi Dietisien, Universitas Esa Unggul, Jakarta, Indonesia \\ Correspondence author: martien.sapang@esaunggul.ac.id
}

\begin{abstract}
One age group that is prone to experiencing nutritional problems, namely toddlers, underfive nutritional intake is a direct cause of nutritional problems. During a pandemic, the consumption of foods that contain balanced nutrients is needed because the body's immunity is needed. Inadequate intake of energy, protein, fat and carbohydrates results in suboptimal nutrition so that they are susceptible to infection. Economic factors also affect the nutritional problems of children under five because the availability of nutritious food is influenced by the socioeconomic conditions of the family. The purpose of this study was to determine the relationship between food consumption, infectious diseases and socioeconomic conditions with the nutritional status $(B B / U)$ of children under five. This research uses quantitative research with cross sectional design and a total sample of 57 children under five who live in the slum settlements of RT 03 Gandasari Village, Tangerang. The collection of data on the characteristics of respondents including age, education level, occupation, infectious diseases and socioeconomic conditions were obtained by interview using a general questionnaire instrument. Nutritional status data with weight / age, food consumption using aquestionnaire food recall $2 \times 24$ hourand analyzed using the Nutrisurvey program. Data analysis used thetest chi square. The results of this study indicate that toddlers have normal nutritional status (57.9\%). The most common infectious diseases were ARI (56.1\%) and diarrhea (38.6\%). Most of the children under five had sufficient levels of energy, protein, fat and carbohydrates intake and low socioeconomic levels (73.7\%). There is no correlation between food consumption $(p=1,000)$, infectious diseases $(p=0.093)$ and socio-economic $(p=0.426)$ on the nutritional status of children under five on the $\mathrm{BB} / \mathrm{U}$.
\end{abstract}

Keywords: Food Consumption, Infectious Diseases, Socio-Economic, Nutritional Status

\begin{abstract}
Abstrak
Salah satu kelompok usia yang rentan mengalami masalah gizi yaitu balita, asupan gizi yang kurang dikonsumsi balita merupakan faktor penyebab langsung terjadinya masalah gizi. Pada masa pandemi, konsumsi pangan yang mengandung zat gizi seimbang sangat dibutuhkan karena diperlukan imunitas tubuh. Asupan energi, protein, lemak dan karbohidrat yang kurang menyebabkan zat gizi tidak optimal sehingga rentan mengalami penyakit infeksi. Faktor ekonomi juga mempengaruhi adanya masalah gizi balita karena tersedianya bahan pangan yang bergizi dipengaruhi oleh sosial ekonomi keluarga. Tujuan penelitian ini adalah untuk mengetahui hubungan konsumsi pangan, penyakit infeksi dan sosial ekonomi dengan status gizi (BB/U) balita. Penelitian ini menggunakan jenis penelitian kuantitatif dengan desain cross sectional dan jumlah sampel 57 balita yang tinggal di permukiman kumuh RT 03 Kelurahan Gandasari Tangerang. Pengumpulan data karakteristik responden meliputi usia, tingkat pendidikan, pekerjaan, penyakit infeksi dan sosial ekonomi diperoleh dengan wawancara menggunakan instrumen kuesioner umum. Data status gizi dengan BB/U, konsumsi pangan menggunakan kuesioner food recall 2x24 jam dan dianalisa menggunakan program Nutrisurvey. Analisis data menggunakan uji chi square. Hasil dari Volume 2 Nomor 01/ Mei 2021




\section{Health Publica}

penelitian ini menunjukkan balita mempunyai status gizi normal (57.9\%). Penyakit infeksi yang sering dialami adalah ISPA $(56,1 \%)$ sedangka diare $(38,6 \%)$. Sebagian besar balita memiliki tingkat asupan energi, protein, lemak dan karbohidrat dalam kategori cukup dan tingkat sosial ekonomi rendah $(73,7 \%)$. Tidak terdapat hubungan konsumsi pangan $(p=1,000)$, penyakit infeksi $(p=0,093)$ dan sosial ekonomi $(p=0,426)$ terhadap status gizi balita indeks $B B / U$.

Kata Kunci: Konsumsi Pangan, Penyakit Infeksi, Sosial Ekonomi, Status Gizi

\section{PENDAHULUAN}

Balita merupakan salah satu kelompok rentan gizi, yaitu mudah menderita gangguan kesehatan dan rentan karena kekurangan gizi. Sejak pandemi covid-19 berlangsung, tercatat angka masalah gizi pada anak meningkat di Indonesia. Apalagi saat ini, dimasa pandemi covid-19 pemenuhan asupan gizi menjadi salah satu faktor yang sangat perlu diperhatikan agar dapat meningkatkan imunitas seseorang untuk mencegah covid-19. Konsumsi makanan yang mengandung zat gizi seimbang sangat dibutuhkan. Pada dasarnya, makanan yang baik merupakan makanan yang dikonsumsi beranekaragam makanan yang mengandung tinggi zat gizi seperti yang terdapat pada karbohidrat, protein, lemak, vitamin dan mineral. Jika seorang balita tidak mencukupi kebutuhan berdasarkan angka kecukupan gizi yang seharusnya antara pemasukan dan pengeluaran, maka dapat menimbulkan permasalahan status gizi. Masalah gizi sudah menjadi masalah besar sebelum pandemi covid-19. Pada tahun 2014 saja terdapat 5,3\% balita di Kota Tangerang mengalami status gizi kurang (Sukoco et al., 2015).

Setiap individu membutuhkan zat gizi yang berbeda dapat dilihat dari usia, jenis kelamin, aktivitas fisik, dan berat badan (Kementerian Kesehatan RI, 2017). Faktor yang mempengaruhi status gizi dipengaruhi oleh makanan, sosial ekonomi seperti tingkat pendidikan, pekerjaan, dan penghasilan keluarga. Penghasilan keluarga merupakan faktor yang dianggap mewakili keadaan sosial ekonomi keluarga (Sebataraja et al., 2014). Saat pandemi Covid-19 di Kelurahan Gandasari Tangerang tingkat ekonomi masyarakat terjadi penurunan sehingga dapat mempengaruhi peluang untuk membeli pangan dengan kuantitas dan kualitas yang lebih baik. Hal ini akan mempengaruhi asupan zat gizi bagi anak. Saat masyarakat terjadi masalah sosial ekonomi karena kehilangan pekerjaan sehingga pendapatan keluarga juga mengalami dampak. Kurangnya asupan zat gizi yang dikonsumsi balita dikarenakan akses makanan yang terbatas, sehingga terdapat anak balita yang mengalami kurang gizi. Anak yang kurang gizi akan cenderung meningkat di tengah angka yang memang sudah tinggi. Hal tersebut sangat penting untuk kekebalan tubuh karena asupan makanan bergizi yang dikonsumsi balita untuk mencegah dan melawan Covid-19 khususnya pada anak balita.

Seiring pertumbuhan penduduk pada suatu daerah, kebutuhan penyediaan sarana dan prasarana juga meningkat. Kurang tersedianya sarana dasar pada saat ini akan mengakibatkan timbuhnya beberapa bagian wilayah perkotaan menjadi kawasan kumuh. Hampir seluruh kota besar yang berada di indonesia mempunyai permasalahan yang sama yaitu permukiman kumuh (Cahya \& Juanda, 2012). Salah satu permukinan kumuh di Kota Tangerang, yaitu wilayah Kelurahan Gandasari Kecamatan Jatiuwung. Letak Kelurahan Gandasari dekat dengan kawasan pabrik dengan keadaan sosial ekonomi yang rendah. Kelurahan Gandasari juga merupakan wilayah penerima raskin tertinggi sejak 2018, yaitu sebanyak 863 rumah tangga (BPS Kota Tangerang dalam Katalog Kecamatan Jatiuwung dalam Angka, 2020).

Pada daerah permukiman kumuh penyakit infeksi yang terdapat pada balita mampu menyebabkan kurangnya status gizi. Apabila balita merasakan penyakit infeksi dan konsumsi pangan yang kurang terutama energi, karbohidrat, protein dan lemak dalam jangka waktu lama sehingga terjadinya penurunan berat badan yang menyebabkan balita mudah terserang penyakit dan 


\section{Health Publica}

penurunan daya tahan tubuh. Menurut data laporan BPS Kota Tangerang, sarana dan prasarana kesehatan di Kelurahan Gandasari kurang memadai, seperti tidak adanya rumah sakit dan jarak permukiman warga ke rumah sakit sekitar 4,2 km. Tetapi terdapat 2 balai pengobatan/poliklinik yang berada di Kelurahan Gandasari. Jarak permukinan dengan puskesmas terdekat letaknya sekitar 2,9 km dari permukiman warga (BPS Kota Tangerang 2020 dalam Katalog Kecamatan Jatiuwung dalam Angka, 2020)

Berdasarkana uraian di atas, diketahui masih banyak anak yang mengalami gangguan status gizi, oleh sebab itu penelitian ini dilakukan dengan tujuan untuk melihat hubungan konsumsi pangan, penyakit infeksi dan sosial ekonomi terhadap status gizi balita di permukiman kumuh RT 03 Kelurahan Gandasari Tangerang Pada Masa Covid-19.

\section{METODE}

Desain penelitian ini yaitu kuantitatif termasuk jenis cross sectional. Penelitian ini dilaksanakan di permukiman kumuh RT 03 Kelurahan Gandasari Tangerang pada bulan November 2020. Populasi dalam penelitian ini adalah anak usia 12-59 bulan yang terdapat di permukiman kumuh RT 03 Kelurahan Gandasari Tangerang, dengan jumlah 57 sampel sesuai dengan yang terdapat pada kriteria inklusi dan eksklusi.

Pengambilan sampel menggunakan dasar teknik purposive sampling, berdasarkan kriteria inklusi dan eksklusi. Variabel yang diteliti terdiri dari variabel independen yaitu konsumsi pangan (asupan energi, protein, lemak dan karbohidrat), penyakit infeksi (diare, ISPA) dan sosial ekonomi sedangkan variabel dependennya yaitu status gizi $(\mathrm{BB} / \mathrm{U})$. Pengumpulan data karakteristik responden meliputi usia, tingkat pendidikan, pekerjaan diperoleh dengan wawancara menggunakan instrumen kuesioner umum. Data konsumsi pangan menggunakan kuesioner food recall $2 \times 24$ jam dan dianalisa menggunakan program Nutrisurvey. Data penyakit infeksi dan sosial ekonomi diperoleh dengan wawancara menggunakan instrumen kuesioner umum. Data karakteristik responden dan data masing-masing variabel dianalisa secara deskriptif. Analisa bivariat untuk menguji kemaknaan hubungan atau korelasi dengan tingkat kepercayaan 95\%. Penelitian ini telah mendapat persetujuan etik yang berasal dari Komisi Etik Penelitian Kesehatan Universitas Esa Unggul, Jakarta nomor : 0050-21.050/DPKE-KEP/FINAL-EA/UEU/III/2021.

\section{HASIL}

Tabel 1 Karakteristik Responden di Permukiman Kumuh

\begin{tabular}{lc}
\hline \multicolumn{1}{c}{ Karakteristik } & $\begin{array}{c}\text { Jumlah sampel } \\
\mathbf{n}=\mathbf{5 7}(\mathbf{\%})\end{array}$ \\
\hline Usia (Tahun) & \\
17-25 Tahun & $14(24.6)$ \\
26-35 Tahun & $33(57.9)$ \\
36-45 Tahun & $10(17.5)$ \\
Tingkat Pendidikan Ibu & \\
SD & $38(66.7)$ \\
SMP & $19(33)$ \\
Pekerjaan Ibu & \\
Buruh & $13(22.8)$ \\
Wiraswasta & $4(7.0)$ \\
Ibu Rumah Tangga & $40(70.2)$ \\
Pekerjaan Ayah & \\
Buruh & $25(43.9)$ \\
Wiraswasta & $8(14.0)$ \\
Serabutan & $24(42.1)$ \\
\hline
\end{tabular}




\section{Health Publica}

Berdasarkan Tabel 1 karakteristik responden permukiman kumuh dalam penelitian yaitu usia, tingkat pendidikan ibu, pekerjaan ibu dan pekerjaan ayah. Data usia menurut Depkes RI Tahun 2009, yaitu remaja (17-25 tahun), dewasa awal (26-35 tahun), dan dewasa akhir (36-45 tahun), dapat diketahui bahwa responden lebih banyak pada kelompok umur 26-35 tahun yaitu 33 orang (57,9\%). Pada tingkat pendidikan Ibu menunjukkan bahwa, responden paling banyak berpendidikan SD sebanyak 38 responden $(66,7 \%)$ dana paling sedikit SMP sebanyak 19 responden (33\%). Pada pekerjaan ibu diketahui paling banyak menjadi ibu rumah tangga 40 responden $(70,2 \%)$, sedangkan pada pekerjaan ayah, diketahui paling banyak bekerja sebagai butuh 25 responden $(43,9 \%)$.

\section{Tabel 2}

Karakteristik Responden Balita di Permukiman Kumuh

\begin{tabular}{|c|c|}
\hline Karakteristik & $\begin{array}{c}\text { Jumlah sampel } \\
\mathbf{n}=\mathbf{5 7}(\%)\end{array}$ \\
\hline \multicolumn{2}{|l|}{ Usia (Bulan) } \\
\hline $12-36$ & $22(38.6)$ \\
\hline $37-59$ & $35(61.4)$ \\
\hline \multicolumn{2}{|l|}{ Jenis Kelamin } \\
\hline Laki-laki & $31(54.4)$ \\
\hline Perempuan & $26(45.6)$ \\
\hline \multicolumn{2}{|l|}{ Status Gizi } \\
\hline Tidak normal & $24(42.1)$ \\
\hline - $\quad$ Berat badan sangat kurang (zscore $\mathrm{BB} / \mathrm{U}<-3 \mathrm{SD}$ ) & \\
\hline - $\quad$ Berat badan kurang (zscore $\mathrm{BB} / \mathrm{U}-3 \mathrm{SD}$ sd $<-2 \mathrm{SD}$ ) & \\
\hline - $\quad$ Berat badan lebih (zscore $\mathrm{BB} / \mathrm{U}>+1 \mathrm{SD})$ & \\
\hline Normal (zscore BB/U -2SD sd +1 SD) & $33(57.9)$ \\
\hline \multicolumn{2}{|l|}{ Penyakit Infeksi } \\
\hline \multicolumn{2}{|l|}{ Kejadian Diare } \\
\hline Iya & $22(38.6)$ \\
\hline Tidak & $35(61.4)$ \\
\hline \multicolumn{2}{|l|}{ Kejadian ISPA } \\
\hline Iya & $32(56.1)$ \\
\hline Tidak & $25(43.9)$ \\
\hline \multicolumn{2}{|l|}{ Pendapatan Keluarga } \\
\hline Rendah $(<4.100 .000)$ & $42(73.7)$ \\
\hline Tinggi $(\geq 4.100 .000)$ & $15(26.3)$ \\
\hline
\end{tabular}

Berdasarkan Tabel 2 karakteristik responden balita di permukiman kumuh dapat dilihat bahwa usia sampel pada kategori 37-59 bulan lebih banyak yaitu 35 responden $(61,4 \%)$. Pada distribusi karakteristik jenis kelamin responden menunjukkan dominan jenis kelamin responden adalah laki-laki yaitu sebanyak 31 responden $(54,4 \%)$. Variabel dependen dalam penelitian ini yaitu status gizi $(\mathrm{BB} / \mathrm{U})$, hasil pengukuran menunjukkan memiliki status gizi normal yaitu 33 responden $(57.9 \%)$.

Variabel independen pada penelitian ini adalah penyakit infeksi (kejadian diare dan ISPA), dan sosial ekonomi/pendapatan keluarga. Dapat dilihat bahwa tidak banyak yang mengalami kejadian diare yaitu 35 responden $(61,4 \%)$ sedangkan lebih banyak yang mengalami kejadia ISPA yaitu 32 responden $(56,1 \%)$. Pada variabel pendapatan keluarga menunjukkan bahwa pendapatan keluaga lebih banyak rendah yaitu 42 responden $(73,7 \%)$. 


\section{Health Publica}

Jurnal Kesehatan Masyarakat

Tabel 3

Konsumsi Pangan Balita di Permukiman Kumuh

\begin{tabular}{lc}
\hline \multicolumn{1}{c}{ Karakteristik } & $\begin{array}{c}\text { Jumlah sampel } \\
\mathbf{n}=\mathbf{5 7}(\mathbf{\%})\end{array}$ \\
\hline Konsumsi Pangan & \\
Asupan Energi & \\
Kurang $(<77 \%$ AKG) & $22(45.6)$ \\
Cukup ( $\geq 77 \%$ AKG) & $31(54,4)$ \\
Asupan Protein & \\
Kurang (<77\% AKG) & $3(5,3)$ \\
Cukup ( $\geq 77 \%$ AKG) & $54(94,7)$ \\
Asupan Lemak & $22(38,6)$ \\
Kurang $(<77 \%$ AKG) & $35(61,4)$ \\
Cukup ( $\geq 77 \%$ AKG) & \\
Asupan Karbohidrat & $37(64.9)$ \\
Kurang $(<77 \%$ AKG $)$ & $20(35.1)$ \\
Cukup $(\geq 77 \%$ AKG) & \\
\hline
\end{tabular}

Berdasarkan Tabel 3 konsumsi pangan balita di permukiman kumuh memperlihatkan jika sebagian besar balita mempunyai konsumsi pangan cukup yaitu pada asupan energi 31 responden (54.4\%), asupan protein 54 responden $(94,7)$, asupan lemak 35 responden $(61,4 \%)$ sedangkan pada asupan karbohidrat kurang yaitu 37 responden (64.9\%).

\section{PEMBAHASAN}

Tabel 4

Hubungan Konsumsi Pangan, Penyakit Infeksi dan Sosial Ekonomi Terhadap Status Gizi di Permukiman Kumuh

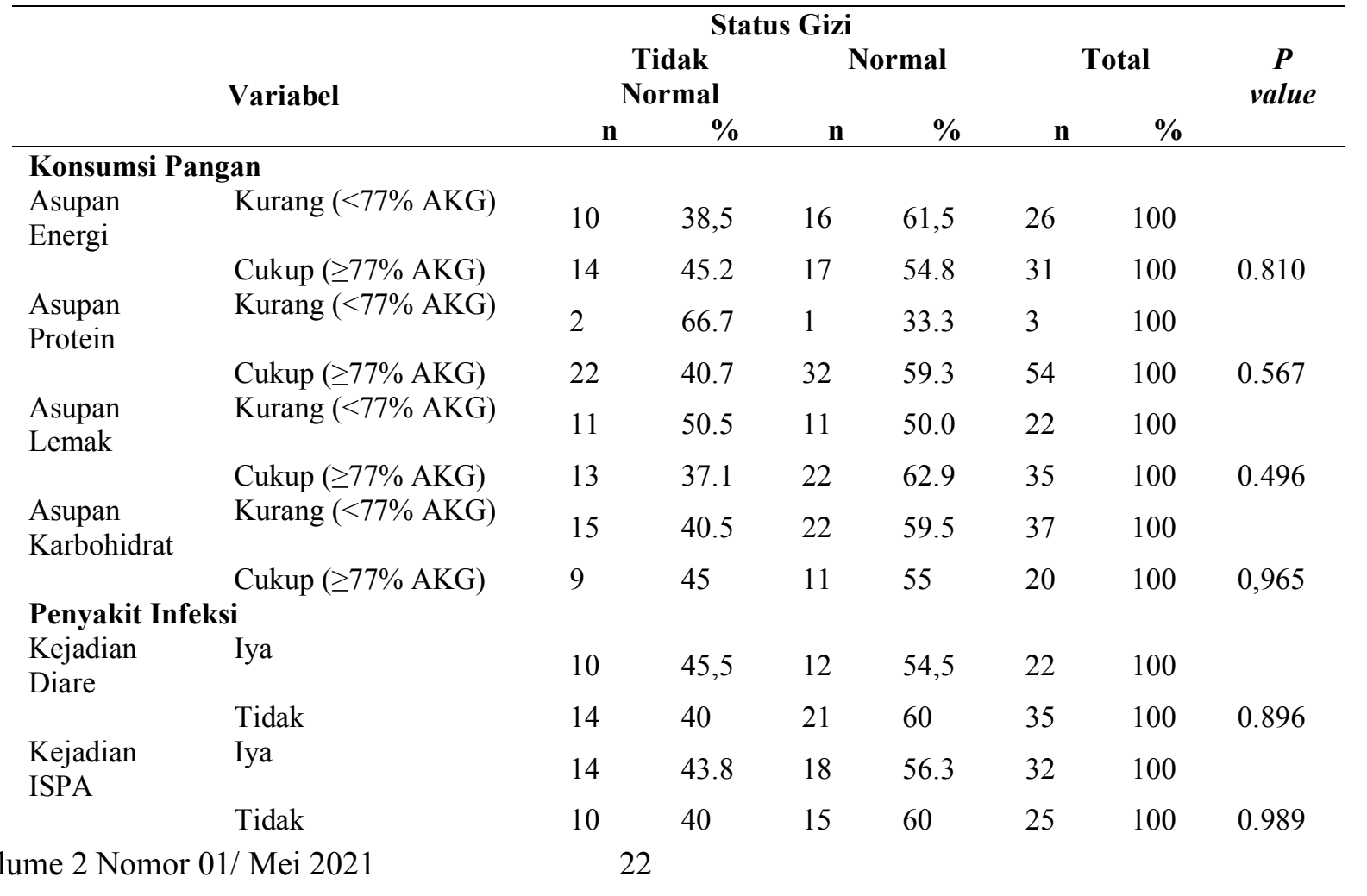




\section{Health Publica}

\begin{tabular}{|c|c|c|c|c|c|c|c|c|}
\hline & \multirow{3}{*}{ Variabel } & \multicolumn{4}{|c|}{ Status Gizi } & & & \multirow{3}{*}{$\begin{array}{c}P \\
\text { value }\end{array}$} \\
\hline & & \multicolumn{2}{|c|}{$\begin{array}{c}\text { Tidak } \\
\text { Normal }\end{array}$} & \multicolumn{2}{|c|}{ Normal } & \multicolumn{2}{|c|}{ Total } & \\
\hline & & $\mathbf{n}$ & $\%$ & $\mathbf{n}$ & $\%$ & $\mathbf{n}$ & $\%$ & \\
\hline \multicolumn{9}{|c|}{ Sosial Ekonomi } \\
\hline \multirow[t]{2}{*}{$\begin{array}{l}\text { Pendapatan } \\
\text { Keluarga }\end{array}$} & Rendah $(<4.100 .000)$ & 18 & 42,9 & 24 & 57,1 & 42 & 100 & \\
\hline & Tinggi $(\geq 4.100 .000)$ & 4 & 26,7 & 11 & 73,3 & 15 & 100 & 0.619 \\
\hline
\end{tabular}

Berdasarkan tabel 4 hubungan konsumsi pangan terhadap status gizi, dapat diketahui asupan energi dengan status gizi dapat dilihat bahwa balita yang mempunyai asupan energi cukup mempunyai status gizi normal yaitu sebesar 54.8\% (17 responden). Hasil uji statistik tidak signifikan pada hubungan antara asupan energi dengan status gizi ( $p$-value $0.810>p$-value 0,05 ). Besari (2014) menyatakan bahwa tidak ada hubungan antara konsumsi energi dengan status gizi kurang pada balita. Berbeda dengan penelitian yang dilakukan oleh Sahalessy et al., (2015) yang menyatakan bahwa terdapat hubungan status gizi $(\mathrm{BB} / \mathrm{U})$ dengan asupan energi di Desa Mopusi. Hal ini berbeda dengan asupan protein. Asupan protein dalam penelitian ini cukup yaitu 59.3\% (32 responden) dan mempunyai status gizi normal. Hasil uji statistik menunjukkan bahwa tidak signifikan pada hubungan antara asupan protein dengan status gizi ( $p$-value $0.567>p$-value 0,05 ). Penelitian ini sejalan yang dilakukan oleh Hendrayati et al., (2013) dan Maradesa et al., (2014) yang menyebutkan bahwa tidak ada hubungan antara asupan protein dengan status gizi.

Pada asupan lemak cukup yaitu $62.9 \%$ (22 responden) dan mempunyai status gizi normal. Hasil uji statistik menunjukkan bahwa tidak signifikan pada hubungan antara asupan protein dengan status gizi ( $p$-value $0.496>$ p-value 0,05$)$. Penelitian ini tidak sejalan yang dilakukan oleh Nindyna Puspasari \& Merryana Andriani (2017) menunjukkan hubungan yang signifikan antara lemak dengan status gizi $(\mathrm{p}=0,001)$. Penelitian terakhir pada konsumsi pangan adalah asupan karbohidrat menunjukkan bahwa asupan karbohidrat kurang mempunyai status gizi normal yaitu 59.5\% (22 responden) sedangkan asupan karbohidrat cukup yaitu 55\% (11 responden) dan mempunyai status gizi normal. Hasil uji statistik menunjukkan bahwa tidak terdapat hubungan antara asupan karbohidrat dengan status gizi ( $p$-value $0,965>p$-value 0,05$)$.

Tidak terdapat hubungan antara konsumsi pangan dengan status gizi kemungkinan dapat terjadi karena hasil wawancara dengan respoden yang tidak sesuai dengan asupan yang sebenarnya. sebagian responden yang mengkonsumsi makanan pokok seperti nasi $2 \mathrm{x}$ sehari dan pada saat food recall responden lupa apa saja yang sudah dikonsumsi sehingga jumlah asupan hasil perhitungan tidak menunjukkan kesesuaian dengan status gizi responden. Selain itu, tidak dapat dipastikan bagaimana kualitas zat gizi yang dimakan dalam periode tertentu dan status gizi balita saat ini adalah pengumpulan dari kebiasaan makan terdahulu balita, Pada saat ini status gizi tidak hanya dipengaruhi oleh asupan makan melainkan juga setiap orang memiliki metabolisme tubuh yang berbeda-beda, seperti kecenderungan tubuh untuk menyimpan makanan lebih banyak daripada yang dikonsumsi sehingga proses metabolisme tubuh berjalan lambat.

Pada hubungan penyakit infeksi terhadap status gizi dapat dilihat bahwa balita yang mengalami kejadian diare mempunyai status gizi tidak normal sebesar 45.5\% (10 responden), sedangkan pada balita yang tidak mengalami kejadian diare mempunyai status gizi normal yaitu $60 \%$ (21 responden). Pada kejadian ISPA yang tidak memiliki kejadian ISPA mempunyai status gizi normal $60 \%$ (15 responden). Hasil uji statistik menunjukkan tidak signifikan pada kejadian diare dengan status gizi ( $p$-value $0.896>p$-value 0,05 ), dan kejadian ISPA ( $p$-value $0.989>p$-value 0,05). Penelitian ini sejalan yang dilakukan oleh Indriati \& Aminingsih (2020) menunjukkan bahwa tidak terdapat hubungan riwayat penyakit infeksi dengan status gizi $(p=0,001)$. Hasil penelitian yang dilakukan oleh Hendrayati et al., (2013) yang memberikan hasil tidak ada hubungan antara penyakit infeksi (diare) dengan status gizi balita. 


\section{Health Publica}

Berdasarkan hasil penelitian kejadian diare pada balita disebabkan oleh tangan yang kotor atau terkontaminasi dapat memindahkan bakteri dan virus pathogen ke makanan. Kejadian diare dapat dimungkinkan karena anak yang mengkonsumsi makanan kurang higienis, apalagi kurangnya kesadaran untuk menjaga kebersihan sangat rendah, seperti tidak mencuci tangan saat makan dan kurangnya air bersih. Sewaktu diare, timbul penyusutan asupan makan, absorpsi zat gizi dan penambahan kebutuhan zat gizi seiring secara bersamaan menimbulkan terjadinya penyusutan berat badan dan menerus ke gagal tumbuh balita. Gangguan gizi bisa mengakaibatkan diare menjadii parah. Dibandingkan kejadian diare pada anak balita yang tidak memiliki masalah gizi. Kejadian ini bisa di cegah dengan memenuhi makanan yang banyak mengandung zat gizi selama anak balita mengalami diare, dan juga ketika anak balita sehat.

Dari hasil penelitian anak yang mengalami penyakit ISPA dimana berdasarkan gejala yang muncul seluruh anak menunjukkan gejala batuk, pilek dan sesak nafas serta tidak ada yang dirawat di rumah sakit. Dari hasil penelitian tersebut menunjukkan gejala ISPA yang dialami anak cenderung pada klasifikasi ISPA bukan pneumonia. ISPA yang dialami seorang balita akan merasakan tidak nafsu makan dan tidak merasa lapar, sehingga terjadi penurunan pada protein dan kalori yang digunakan untuk pertumbuhan. Keadaan gizi yang kurang akan terjadinya faktor risiko penyakit ISPA. Balita dengan gizi kurang akan lebih mudah terserang penyakit ISPA dibandingkan dengan balita dengan gizi normal karena terdapat faktor daya tahan tubuh yang kurang. Penyakit infeksi yang dialami seorang balita akan merasakan tidak nafsu makan dan tidak merasa lapar,(Nengsi \& Risma, 2017). Terjadinya ISPA pada balita dipengaruhi oleh pencemaran udara dari kegiatan pabrik, pada mulanya sering mengeluarkan asap, debu, dan limbah yang berupa hasil pembakaran ke udara sekitar tersebut lalu terhirup oleh masyarakat. Hasil penelitian ini sejalan dengan penelitian Halim \& Pambudi (2019) yang menyatakan bahwa tidak signifikan antara kejadian ISPA dengan status gizi $(p=0,072)$. Penelitian ini juga melihatkan hasil yang sama dengan penelitian Indriati \& Aminingsih (2020), yaitu tidak terdapat hubungan riwayat ISPA dengan status gizi anak $(\mathrm{p}=0.693)$. Sementara penelitian yang lain menunjukkan bertentangan dengan penelitian ini yang dilakukan oleh AshSiddiq (2018), frekuensi ISPA berhubungan dengan status gizi balita. Semakin tinggi frekuensi ISPA maka status gizi balita semakin kurang.

Tidak terdapat hubungan penyakit infeksi dengan status gizi, hal ini dikarenakan kondisi penyakit infeksi di penelitian ini hanya terbatas satu bulan, sehingga masih kurang untuk menggambarkan hasil dari penyakit infeksi tersebut. Pada penelitian ini penyakit infeksi mempunyai status gizi normal, hal ini dikarenakan kuesioner dalam penelitian menggambarkan dalam 3 bulan terakhir penyakit infeksi sedangkan status gizi yang di ukur pada saat penelitian berlangsung, perbedaanyaa hanya saat anak balita mempunyai status gizi normal pemulihan terhadap penyakitnya bisa lebih cepat dari pada balita yg berstatus gizi tidak normal, dimana pada status gizi anak yang kurang penyakit infeksi dapat menyerang sangat lama melalui penyusutan nafsu makan.

Pada hubungan sosial ekonomi terhadap status gizi BB/U, diketahui bahwa keluarga dengan pendapatan rendah mempunyai status gizi normal 57,1\% (24 responden), sedangkan keluarga dengan pendapatan tinggi mempunyai status gizi normal yaitu 73,3\% (11 responden). Menurut uji chi square, tidak ada hubungan yg signifikan antara pendapatan kluarga dengan status gizi BB/U. Penelitian ini mempunyai selisih dengan penelitian yang dilakukan Handini et al., (2013). Dari hasi uji statistik dengan chi square dengan $P<0,05$ hasil ini memperlihatkan bahwa pendapatan keluarga adalah salah satu timbulnya gangguan gizi pada anak usia dua sampai tiga tahun di puslesmas kalijambe, untuk mengukur tingkat pendapatan sangat sulit karena pendapatan juga dipengaruhi oleh jumlah anggota keluarga.

Tidak terdapat hubungan antara pendapatan keluarga dengan status gizi kemungkinan dapat terjadi karena hanya hanya ayah yang bekerja untuk menghasilkan pendapatan keluarga dan ibu 


\section{Health Publica}

sebagai ibu rumah tangga. Pada saat Covid-19 kehilangan pendapatan rumah tangga terjadi secara tiba-tiba sehingga menimbulkan ketidakstabilan situasi ekonomi keluarga dan dapat berujung pada kemiskina, sehingga mengalami dampak berat dalam keamanan pangan rumah tangga dan keterbatasan terkait akses, ketersediaan makanan dan keterjangkauan bahan makanan sehat sehingga balita sulit untuk mendapatkan makanan sehat. Selain itu Kelurahan Gandasari juga merupakan wilayah penerima raskin tertinggi sejak 2018, yaitu sebanyak 863 rumah tangga (BPS Kota Tangerang dalam Katalog Kecamatan Jatiuwung dalam Angka, 2020). Saat pandemi Covid-19 rendahnya tingkat sosial ekonomi di Kelurahan Gandasari Tangerang, meskipun sosial ekonomi kurang tetapi mendapatkan bantuan dari pemerintah untuk mempengaruhi asupan zat gizi bagi anak.

\section{KESIMPULAN}

Berdassarkan hasil penelitian diperoleh simpulan bahwa tidak ada hubungan antara asupan energi $(p=0.810)$, asupan protein $(p=0.567)$, asupan lemak $(p=0,496)$, asupan karbohidrat $(p=$ $0.496)$, kejadian diare $(p=0.896)$, kejadian ISPA $(p=0,989)$, dan sosial ekonomi $(p=0.619)$ terhadap status gizi BB/U. Disarankan untuk ibu dari balita untuk lebih memperhatikan konsumsi makanan sesuai dengan kebutuhan gizi setiap balita dan mengonsumsi makanan beraneka ragam makanan yang bergizi.

\section{UCAPAN TERIMA KASIH}

Terima kasih kepada responden serta kepada semua pihak yang telah berkontribusi dalam penelitian ini, sehingga penelitian ini dapat terselesaikan dengan baik. Manuskrip ini telah diikutkan pada Scientific Article Writing Training (SAWT) Batch IV Program Kerja GREAT 4.1.e, Program Studi S1 Gizi, FIKES, Universitas Esa Unggul dengan dukungan fasilitator: Dudung Angkasa, SGz., M.Gizi, RD; Khairizka Citra Palupi, SGz., MS; beserta tim dosen prodi Ilmu Gizi lainnya. SAWT Batch IV juga mendapat dukungan dana dari Universitas Esa Unggul.

\section{DAFTAR PUSTAKA}

AshSiddiq, N. A. (2018). Penyakit Infeksi Dan Pola Makan Dengan Kejadian Status Gizi Kurang Berdasarkan Bb/U Pada Balita Usia 6-24 Bulan Di Wilayah Kerja Puskesmas Tanah Sepenggal. Scientia Journal, 7(2), 158-165.

Besari, D. A. (2014). Determinan Faktor Yang Mempengaruhi Status Gizi Kurang Pada Balita Di Desa Branta Pesisir Dan Desa Tlanakan Kecamatan Tlanakan kabupaten Pamekasan. Jurnal Tata Boga, 3(3), 8-13. http://jurnalmahasiswa.unesa.ac.id/index.php/jurnal-tataboga/article/view/8134/baca-artikel

BPS Kota Tangerang 2020 dalam Katalog Kecamatan Jatiuwung dalam Angka. (2020). Kecamatan Jatiuwung Dalam Angka 2020.

Cahya, D. L., \& Juanda, N. (2012). Penataan Kawasan Kumuh (Pulo Geulis) Kelurahan Babakan Pasar Kecamatan Bogor Tengah Kota Bogor. Jurnal Planesa (Planologi), 3(1).

Halim, Y., \& Pambudi, W. (2019). Hubungan Status Gizi dengan Prevalensi ISPA Pada Anak Usia 6 - 24 Bulan di Puskesmas Wilayah Kota Administratif Jakarta Barat Periode Januari - April 2017. Tarumanagara Medical Journal, 1(2), 428-433.

Handini, D., Ichsan, B., \& Nirlawati, D. D. (2013). Hubungan Tingkat Pendapatan Keluarga Dengan Status Gizi Balita Di Wilayah Kerja Puskesmas Kalijambe. Biomedika, 5(2). https://doi.org/10.23917/biomedika.v5i2.263

Hendrayati, Amir, A., \& Darmawati. (2013). Faktor Yang Mempengaruhi Kejadian Wasting Pada Anak Balita di Kecamatan Marioriwawo Kabupaten Soppeng. Media Gizi Pangan, XV(1), 5661. 


\section{Health Publica}

Indriati, R., \& Aminingsih, S. (2020). Hubungan Riwayar Penyakit ISPA dan Diare Dengan Status Gizi Pada Anak Usia 1-5 Tahun. Jurnal Ilmu Kesehatan, 8(1).

Kementerian Kesehatan RI. (2017). Buku Saku Pemantauan Status Gizi. Buku Saku Pemantauan Status Gizi Tahun 2017, 7-11.

Maradesa, E., Kapantow, N. H., \& Punuh, M. I. (2014). Hubungan Antara Asupan Energi dan Protein Dengan Status Gizi Anak Usia 1-3 Tahun di Wilayah Kerja Puskesmas Walantakan Kecamatan Langowan. 1-8.

Nengsi, S., \& Risma. (2017). Hubungan Penyakit Infeksi dengan Status Gizi Balita di Wilayah Kerja Puskesmas Anreapi Kabupaten Polewali Mandar. Jurnal Kesehatan Masyarakat, 3(1).

Nindyna Puspasari, \& Merryana Andriani. (2017). Hubungan Pengetahuan Ibu tentang Gizi dan Asupan Makan Balita dengan Status Gizi Balita (BB/U) Usia 12-24 Bulan. Amerta Nutrition, 1(4), 369-378. https://doi.org/10.20473/amnt.v1.i4.2017.369-378

Sahalessy, R. K. F., Kapantow, N. H., \& Mayulu, N. (2015). Hubungan Antara Asupan Energi Dengan Status Gizi Batita Umur 1-3 Tahun Di Desa Mopusi Kecamatan Bolaang Mongondow Induk Sulawesi Utara 2014. Jurnal E-Biomedik, 3(3), 1-5. https://doi.org/10.35790/ebm.3.3.2015.9362

Sebataraja, L. R., Oenzil, F., \& Asterina, A. (2014). Hubungan Status Gizi dengan Status Sosial Ekonomi Keluarga Murid Sekolah Dasar di Daerah Pusat dan Pinggiran Kota Padang Lisbet Rimelfhi Sebataraja,. Jurnal Kesehatan Andalas, 3(2), 182-187. https://doi.org/10.25077/jka.v3i2.81

Sukoco, noor edi widya, Pambudi, J., \& Herawati, maria holly. (2015). Hubungan Status Gizi Anak Balita Dengan Orang Tua Bekerja. Buletin Penelitian Sistem Kesehatan, 18(4), 387-397. 